\title{
Wilms Tumor-1 (WT1) rs16754 Polymorphism and Clinical Outcome in Acute Myeloid Leukemia
}

\author{
Akut Myeloid Lösemide Wilms Tumor-1 (WT1) rs16754 Polimorfizmi ve Klinik Seyir
}

(D) Mani Ramzi, (D) Mohamad Moghadam, (D) Nader Cohan

Shiraz University of Medical Sciences, Hematology Research Center, Shiraz, Iran

To the Editor,

Cytogenetic evaluation and risk stratification are important steps in the classification of acute myeloid leukemia (AML) and also in determining the best treatment modality. Although cytogenetically normal acute myeloid leukemia (CN-AML) represents a large group of adult patients with AML (about 45\% of AML patients), several mutations in some genes including FLT3, NPM1, CEBPA, and WT1 are associated with risk assessment and clinical outcome [1,2]. The WT1 gene is located on chromosome $11 \mathrm{p} 13$ and was detected first as a tumor-suppressor gene in Wilm's tumor; it also has a regulatory role in normal and malignant hematopoiesis [3]. WT1 gene mutations in CN-AML were reported in about $10 \%$ of patients and its role as a sole prognostic factor is controversial $[4,5,6]$. The most important WT1 gene mutations associated with AML are clustered in the hotspot region of exon 7 and a synonymous single nucleotide polymorphism (SNP), rs16754, is also located in this region. Some studies were done for evaluation of WT1 rs16754 polymorphism effects on clinical response in AML patients. Most studies confirmed that rs16754 $(A>G)$ in the hotspot region of exon 7 is a predictive independent positive prognostic factor in AML patients. Two meta-analyses were published for evaluation of these results. Megias-Vericat et al. [7] performed the first metaanalysis in this regards with a total of 3618 included patients from 14 cohort studies. They found that the overall survival (OS) at 5 years was significantly higher in patients with the variant allele (G) together with higher disease-free survival (DFS) with the variant allele. Although they did not find any significant effect of this variant on complete remission (CR), they stated that the lack of an observable effect could have been a result of the small number of studies that evaluated it. Long et al. [8] also published a meta-analysis in this regard, addressing 12 publications with 3903 included patients. Although some of the publications and included patients in those two studies may have been the same, they found the same results for the significant effects of WT1 rs16754 polymorphism on OS and relapse-free survival. In a newly published study Petiti et al. [9] also showed that patients with mutated genotypes ( $G G$ and GA) have a significantly better OS and event-free survival (EFS) compared with patients with wild AA mutation (84 vs. 9 months for OS and 23 vs. 3 months for EFS). They discussed that they used peptide nucleic acid-directed PCR clamping technology for this study.

In a prospective study, we evaluated the effects of the rs 16754 SNP on clinical outcome in CN-AML patients. From December 2012 to December 2016, a total of 108 untreated adult patients who were referred to Nemazee Hospital, Shiraz University of Medical Sciences, and diagnosed with CN-AML were included. The exclusion criterion was abnormality upon karyotyping. The diagnosis was based on peripheral blood and bone marrow aspiration confirmed by immunophenotyping and the treatment was based on standard induction chemotherapy, which consisted of daunorubicin at $45 \mathrm{mg} / \mathrm{m}^{2}$ on days 1 to 3 and cytarabine at $100-200 \mathrm{mg} / \mathrm{m}^{2}$ on days 1 to 7 , followed by high doses of a cytarabine-based consolidation phase (cytarabine at $3 \mathrm{~g} / \mathrm{m}^{2}$ every $12 \mathrm{~h}$ for 3 days, repeated for 3 to 6 cycles). Informed consent was obtained from all patients and the work was carried out in accordance with the code of ethics of the World Medical Association (Declaration of Helsinki) for experiments in humans. The rs16754 $(A>G)$ polymorphism in exon 7 was evaluated in all patients by direct sequencing of the amplified and purified PCR products. OS and DFS were assessed for evaluation of clinical outcome. The allele frequency of the A allele was 181 and that of the $G$ allele was 35 . The major genotype (AA) was found in 79 patients and a minor genotype in 29 patients ( $\mathrm{AG}$ and $\mathrm{GG}$ in $23(21.3 \%)$ and 6 (5.5\%) patients, respectively). We found no significant difference between patients with the wild and variant allele based on CR and relapse as well as OS and DFS, which may be a result of the small number of included patients. The results are shown in Table 1. Although the exact reason for the effects of this SNP on clinical outcome in AML patients is unclear, different hypotheses exist, including increased rate of translation and protein folding in mutated genotypes, disequilibrium linkage of this SNP with another genetic variant that affects drug metabolism, and greater sensitivity of mutated genotypes to cytarabine $[7,10]$. In conclusion, the WT1 rs16754 polymorphism may be a reliable independent prognostic factor in AML and could be assessed for risk stratification in this group of patients, although more studies including larger study groups are needed for more evaluation and discussion. 


\begin{tabular}{|c|c|c|}
\hline \multicolumn{3}{|c|}{$\begin{array}{l}\text { Table } 1 . \text { Clinical and laboratory data according to rs } 16754 \\
\text { wild and minor alleles. }\end{array}$} \\
\hline Characteristic & $\begin{array}{l}\text { rs16754 } \\
\text { wild allele } \\
\text { (AA) } \\
n=79\end{array}$ & $\begin{array}{l}\text { rs } 16754 \\
\text { minor allele } \\
\text { (AG or GG) } \\
n=29\end{array}$ \\
\hline Age (years) & $40 \pm 16$ & $41 \pm 12$ \\
\hline $\operatorname{Sex}(M / F)$ & $43 / 36$ & $16 / 13$ \\
\hline Primary WBC count $\left(\times 10^{9} / \mathrm{L}\right)$ & $39.9 \pm 11.8$ & $41.2 \pm 13.4$ \\
\hline Platelet count ( $\left.\times 10^{9} / \mathrm{L}\right)$ & $75.9 \pm 34.5$ & $74.6 \pm 39.7$ \\
\hline Hemoglobin level (g/L) & $81 \pm 19$ & $83 \pm 24$ \\
\hline Bone marrow blast (\%) & $78.3 \pm 13.9$ & $77.2 \pm 128$ \\
\hline Complete remission (\%) & $51(64.5 \%)$ & $21(72.4 \%)$ \\
\hline Relapse after complete remission (\%) & $38(48.1 \%)$ & $14(48.2 \%)$ \\
\hline Mean overall survival (months) & $15.7 \pm 3.2$ & $16.1 \pm 1.6$ \\
\hline Mean disease-free survival (months) & $14.6 \pm 3.8$ & $14.9 \pm 2.7$ \\
\hline \multicolumn{3}{|c|}{$\begin{array}{l}p>0.05 \text { was noted according to overall survival and disease-free survival between the } \\
\text { two groups. }\end{array}$} \\
\hline \multicolumn{3}{|l|}{ M: Male, F: female, WBC: white blood cell. } \\
\hline
\end{tabular}

Keywords: Polymorphism, Acute myeloid leukemia, Clinical outcome

Anahtar Sözcükler: Polimorfizm, Akut miyeloid lösemi, Klinik seyir

Informed Consent: Received.

Conflict of interest: The authors of this paper have no conflicts of interest, including specific financial interests, relationships, and/or affiliations relevant to the subject matter or materials included.

\section{References}

1. Bhatnagar B, Garzon R. The use of molecular genetics to refine prognosis in acute myeloid leukemia. Curr Hematol Malig Rep 2014;9:148-157.

2. Ghanem H, Tank N, Tabbara IA. Prognostic implications of genetic aberrations in acute myelogenous leukemia with normal cytogenetics. Am J Hematol 2012;87:69-77.

3. Ariyaratana S, Loeb DM. The role of the Wilms tumour gene (WT1) in normal and malignant haematopoiesis. Expert Rev Mol Med 2007;9:1-17.

4. Gaidzik VI, Schlenk RF, Moschny S, Becker A, Bullinger L, Corbacioglu A, Krauter J, Schlegelberger B, Ganser A, Döhner H, Döhner K. Prognostic impact of WT1 mutations in cytogenetically normal acute myeloid leukemia: a study of the German-Austrian AML Study Group. Blood 2009;113:45054511.

5. Rampal R, Figueroa ME. Wilms tumor 1 mutations in the pathogenesis of acute myeloid leukemia. Haematologica 2016;101:672-679.

6. Gaidzik V, Döhner K. Prognostic implications of gene mutations in acute myeloid leukemia with normal cytogenetics. Semin Oncol 2008;35:346355.

7. Megias-Vericat JE, Herrero MJ, Rojas L, Montesinos $P$, Bosó V, Moscardó $F$, Martínez-Cuadrón D, Poveda JL, Sanz MÁ, Aliño SF. A systematic review and meta-analysis of the impact of WT1 polymorphism rs16754 in the effectiveness of standard chemotherapy in patients with acute myeloid leukemia. Pharmacogenomics J 2016;16:30-40.

8. Long J, Fang S, Dai Q, Liu X, Zhu W, Wang S. The Wilms tumor-1 (WT1) rs 16754 polymorphism is a prognostic factor in acute myeloid leukemia (AML): a meta-analysis. Oncotarget 2016;7:32079-32087.

9. Petiti J, Rosso V, Lo lacono M, Calabrese C, Signorino E, Gaidano V, Berger M, Saglio G, Cilloni D. Prognostic significance of the Wilms' tumor-1 (WT1) rs16754 polymorphism in acute myeloid leukemia. Leuk Res 2018;67:6-11.

10. Damm $F$, Heuser $M$, Morgan $M$, Yun $H$, Grosshennig $A$, Göhring $G$, Schlegelberger $B$, Döhner $K$, Ottmann 0 , Lübbert $M$, Heit $W$, Kanz $L$, Schlimok G, Raghavachar A, Fiedler W, Kirchner H, Döhner H, Heil G, Ganser A, Krauter J. Single nucleotide polymorphism in the mutational hotspot of WT1 predicts a favorable outcome in patients with cytogenetically normal acute myeloid leukemia. J Clin Oncol 2010;28:578-585. 